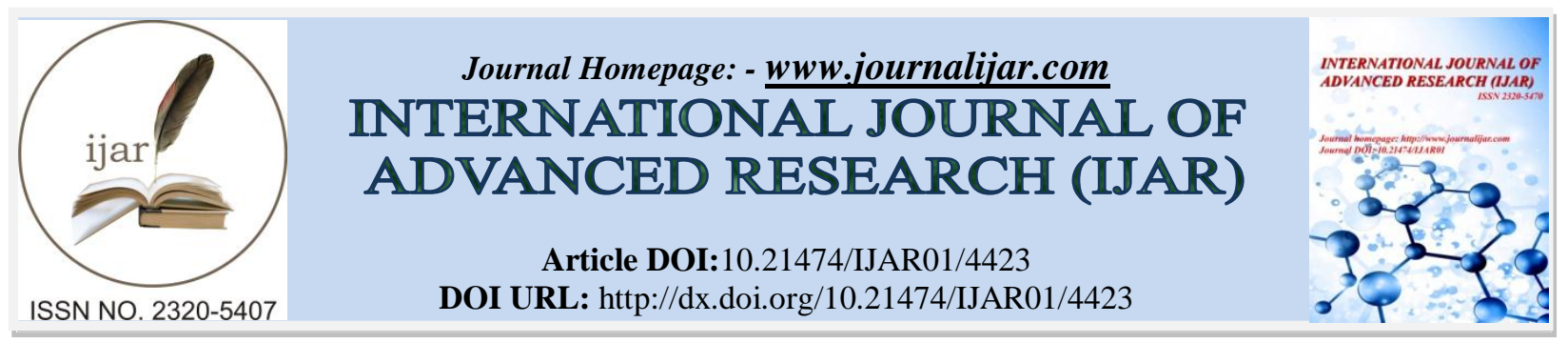

RESEARCH ARTICLE

\title{
FOLIAR DUST ACCUMULATION POTENTIAL OF SOME SELECTED PLANT SPECIES GROWN ALONGSIDE THE HIGHWAY AT SUGANDHA, HOOGHLY, WEST BENGAL, INDIA.
}

\author{
Monalisa Das, Moumita Das* and Ambarish Mukherjee.
}

UGC Centre for Advanced Study (Phase II), Department of Botany, The University of Burdwan- 713104, India.

\section{Manuscript Info}

\section{Manuscript History}

Received: 09 April 2017

Final Accepted: 11 May 2017

Published: June 2017

Key words:-

Urban air pollution, particulate matters (SPM), Dust capturing potential, foliar dust deposition, natural filters.

\section{Abstract}

The increasing Vehicular exhaust has a significant contribution on urban air pollution. Roadside Plants have to suffer a lot from automobile exhaust and dust particles. The ability of each plant species to captured particulate matters (SPM) by their foliar surface varies greatly and depends on several surface characteristics of twigs, bark and foliage of the plants. The present study was undertaken along the State Highway SH 13 road side of Sugandha located in the Hooghly, West-Bengal, India to assess the Dust capturing potential of some selected plant species . Results showed that dust accumulation on the leaves ranged from $0.00102 \mathrm{~g} / \mathrm{cm}^{2}$ in Tabernaemontana divaricata to $0.003225 \mathrm{~g} / \mathrm{cm}^{2}$ in Mangifera indica and followed the descending order of pollutant sink as Albizia saman $\left(0.00296 \mathrm{~g} / \mathrm{cm}^{2}\right)>$ Ficus racemosa $\left(0.00292 \mathrm{~g} / \mathrm{cm}^{2}\right)>$ Cajanus cajan $\left(0.00266 \mathrm{~g} / \mathrm{cm}^{2}\right)$. The study determined a set of plant species that have high potential of foliar dust deposition which will help determine the optimal plant species to be used as natural filters to mitigate particulate roadside pollution.

Copy Right, IJAR, 2017,. All rights reserved.

\section{Introduction:-}

Rapid industrialization, new invention, urbanization, population growth, and progress of construction activity has perturbed environment are responsible for changing urban ecosystems and disturbances. Day by day increasing traffic load may generate exceptionally high dust concentration along the road side area close to exceed environmental guideline values (Leys et al., 1998; Manins et al., 2001) which will become a big challenge for human civilization in near future. Motor vehicles are Responsible for $60-70 \%$ of the pollution and Suspended Particulate Matter (SPM) commonly known as dust constituents $40 \%$ of total air pollution problems in India (Kaler et al., 2016). Among the Chronic pollutants, carbon monoxide, lead, ground-level ozone, nitrogen dioxide, particulate matter, and sulfur dioxide are most important. Several studies have revealed that the dust contains heavy metals like $\mathrm{Cu}, \mathrm{Ni}, \mathrm{Pb}, \mathrm{Zn}$, etc. also contributes toxic pollutant to the air(Bhattacharya et al., 2011) may cause adverse health effects in humans, affect plant life, deteriorating ecosystem and changing environmental atmosphere of the earth which attracts global attention during last few decades. Dust means solid particles of 2.5-10 $\mu \mathrm{m}$ in atmosphere are responsible for deteriorating health of local public (Borja-Aburto, et al., 1998; Beckett, et al., 1998).

Plant leaves act as constant absorbers for particulate matters can be improved the air quality in urban areas by planting trees along road sides (Samal and Santra, 2002). The vegetation type and seasonal variation in dustfall has 
impact on accumulation and deposition of gaseous pollutants and particulate matter (Fowler et al., 1989; Prajapati and Tripathi, 2008).So it becomes necessary to identifying such potential bio-filter plants is of significance in dust deposition/capture. Dust interception capability of plants depends on their range of characteristics of leaf such as surface geometry, phyllotaxy, leaf external characteristics (hairs, cuticle etc.) and height of trees.Green vegetation suffered from a variety of ailments due to phytotoxic dust pollution leads to ill effects on the plants health.Dust settles on leaf surface interrupts the light causes the physical and physiological damage of the leaves like reduce chlorophyll content, inhibition in photosynthesis leaf defoliation, chlorosis, necrosis, bronzing, defective margin or tip, etc. The direct physical effects apparent only at relatively high surface loads (Nitesh et al. 2017). Various biochemical changes such as decreased chlorophyll content and increased ascorbic acid content responses ultimately accelerate the process of senescence (Prajapati and Tripathi, 2008).

Presence of trees in the urban environment play an important role in maintaining the ecological balance by actively enhancing cycling the nutrients and gases like $\mathrm{Co}_{2}$ and $\mathrm{O}_{2}$ and providing enormous leaf area for Removal of pollutants by deposition and absorption of particulates, aerosols over leaf surfaces and fallout of particulates on the leeward side of the vegetation due to slowing of the air movement .As initial acceptors, Plants use for monitoring air pollution has long been established (Prajapati and Tripathi, 2008).

Several studies have been performed on the impacts of dust deposition capacity of different plants species in urban areas however, a plant's response may alter under varying pollution stress (Rai, 2016). In recent it has been realized that plant act as a low price eco- sustainable tool for controlaing and monitoring air pollution. So the present study was planned to investigate foliar dust retention capacity of selected plant species grown along the road side to observed the variation in foliar dust deposition of different species and provide essential data for the recognition and control of air quality as well as for further environmental study.

\section{Materials and Methods:- Study Area Selection:-}

Road site areas of sugandha (map reference) were selected for foliar dust capturing evaluationon the basis of traffic density, high dust concentration. The sampling was carried out during April, 2017 because weather remains dry during these months. Sugandha is a village panchayat located in the Hooghly district of West-Bengal state,India. The latitude $22^{\circ} 54^{\prime} 27.52^{\prime \prime} \mathrm{N}$ and longitude 88.20'22.99'E covers the total 127.13 hectares area .It belongs to Burdwan Division. It is located $6 \mathrm{KM}$ towards west from District head quarters Hooghlychuchura. 43 KM from State capital Kolkata . Chinsurah, Hooghly, Chandannagar, Naihati are the nearby Cities to Sugandha. State Highway SH 13 originates from junction with NH 114 and NH 19 at Palsit (in Bardhaman district) and passes through the area. Also Chunchura-Dhaniakali Road crossing the area. This is subjected to heavy traffic density. Besides, few factories on both side of the highway continuously polluting the ambient air quality of this region which ultimately influencing plant vegetation and human health. Determination of leaf dust accumulation from the areas generally employed for identifying tolerance level of plant species. 


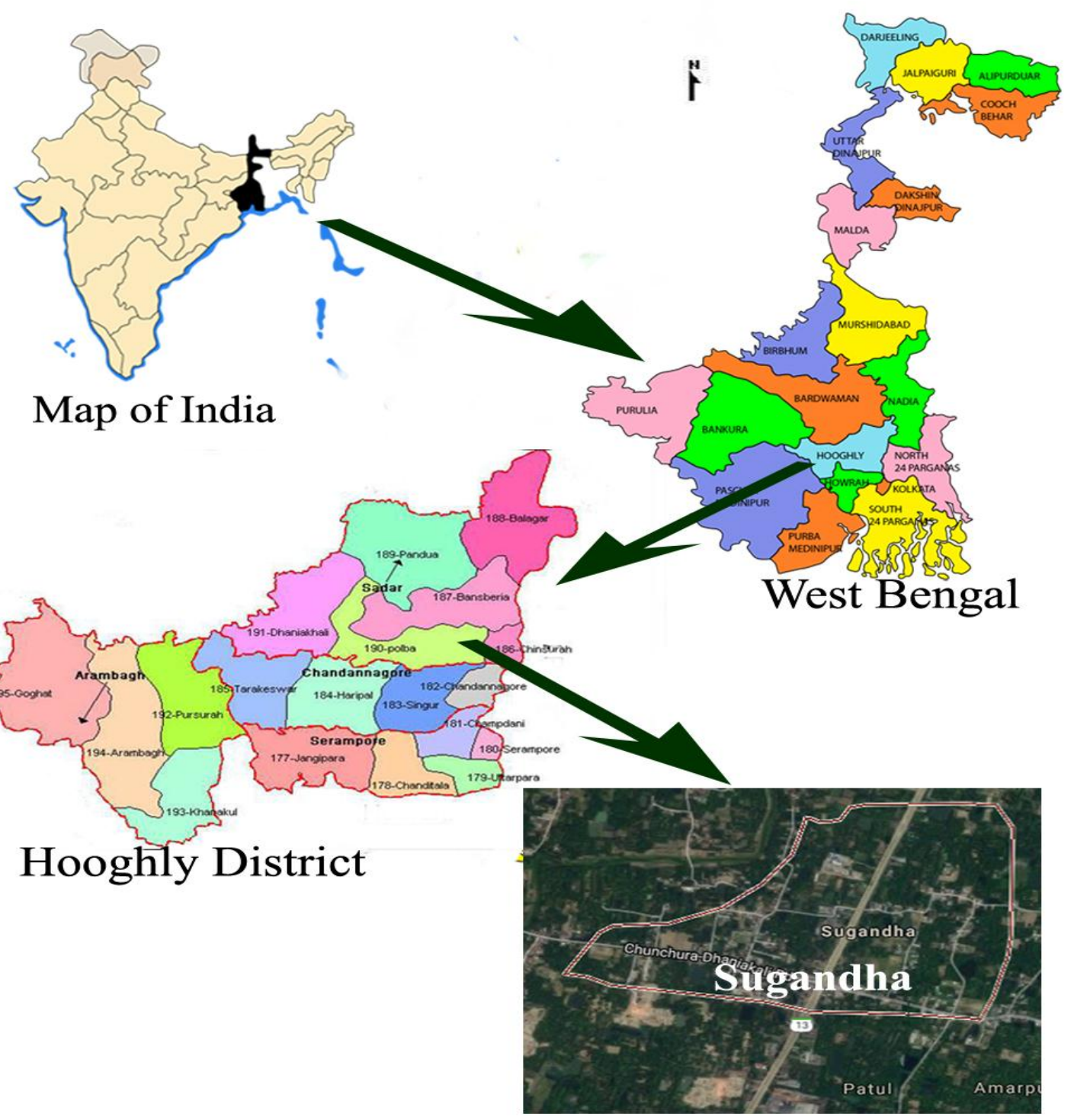

Figure 1: -Map showing the study area, Sugandha in Hooghly district of West Bengal, India

\section{Study Material:-}

Total of twelve plants, one individual from each species were taken for foliar dust retention evaluation. These plants (Albizia saman (Jacq.) Merr., Citrus maxima (Burm.) Merr., Ficus racemosa L., Saraca asoca (Roxb.) Willd., Tabernaemontana divaricata (L.) R.Br. ex Roem. \& Schult., Artocarpus heterophyllus Lam., Hibiscus rosasinensis L., $\quad$ Nerium oleander $\mathrm{L}$., $\quad$ Mangifera indica $\mathrm{L}$., $\quad$ Ixora coccinea $\mathrm{L} ., N y c t a n t h e s$ arbor-tristis $\mathrm{L}$., Cajanus cajan (L.) Millsp) (http: //www.theplantlist.org.) were common and thus growing near road side were selected for the study.Th e selected plant species and their characteristics, including leaf characteristics, are given in Table 1.Plants height measured by altimeter. 
Table.1:-Description of selected plants at study site with leaf Characteristics.

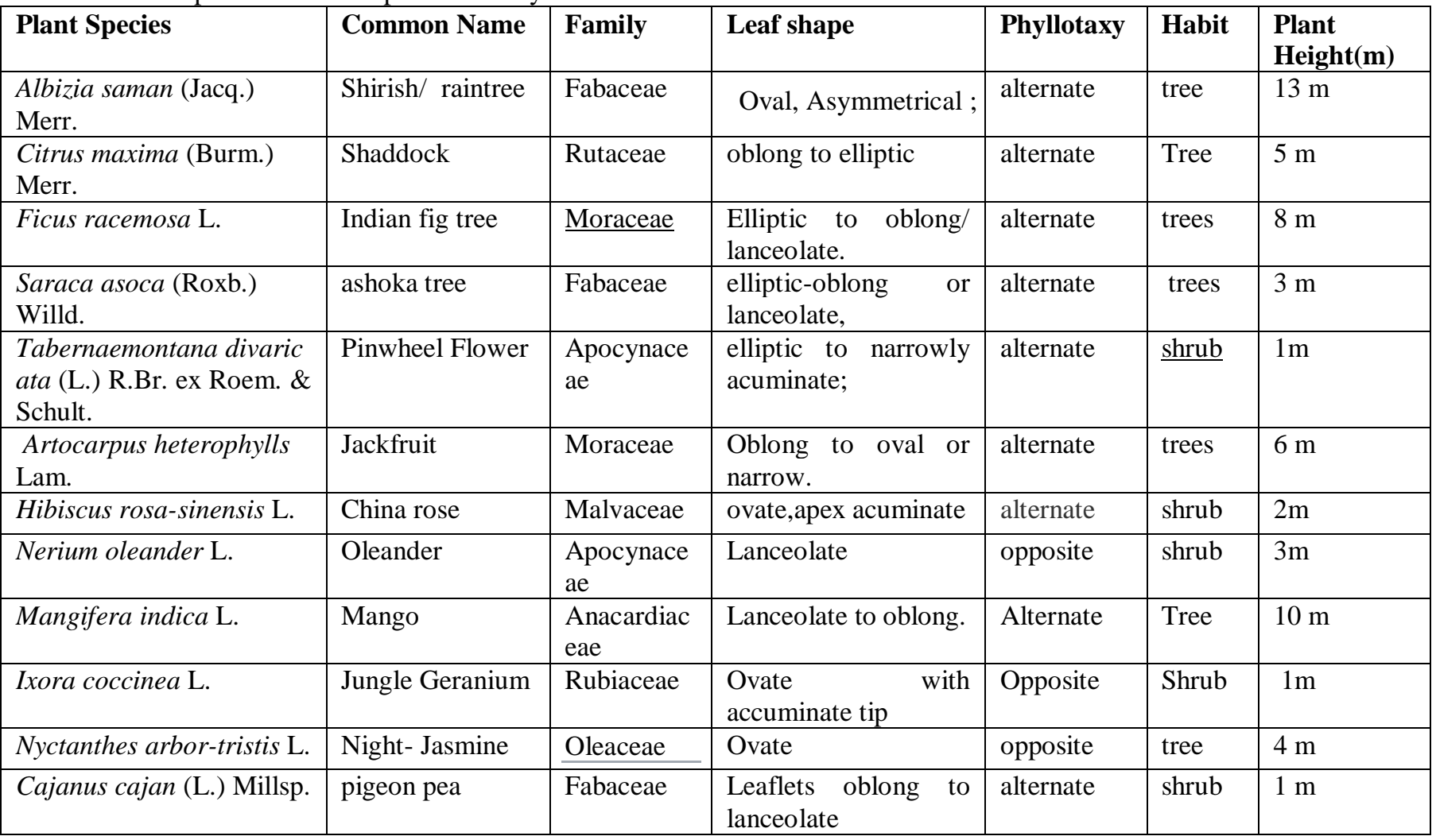

\section{Leaf dust Accumulation:-}

Five leaves per plant were collected from the branches of different heights facing towards the roadside in the early morning 6.30 AM to 8.30 AM through random selection and were put in polythene bags. Leaves were brought to Laboratory and washed with $50 \mathrm{~mL}$ deionised water in $100 \mathrm{ml}$ beakers, and shaken by a sonicator for $30 \mathrm{~s}$, which repeated twice. The resulting water was carefully collected on pre-weighed Whatman's filter paper No 1 . The loaded filter paper was then oven dried at $600 \mathrm{C}$ and later weighed to calculate the dust fall. Dust retention was calculated based on weight differences between oven dried filter paper before and after filtrations. The samples were weighed using an electronic balance and the amount of dust was calculated using the equation (Swain et al., 2016; Kaler et al., 2016; Prajapati and Tripathi, 2008)

$$
\mathbf{W}=\left(\mathbf{W}_{2}-\mathbf{W}_{1}\right) / \mathbf{a}
$$


Table 2:- List of the meteorological data for determination of dust capturing potential of selected plant species

\begin{tabular}{|c|c|c|c|c|c|c|c|c|c|}
\hline Name of Plant & $\begin{array}{l}\text { No. of } \\
\text { replica }\end{array}$ & $\begin{array}{l}W_{1} \\
(g)\end{array}$ & $\begin{array}{l}W_{2} \\
(g)\end{array}$ & $\begin{array}{l}\mathbf{L} \\
(\mathbf{c m})\end{array}$ & $\begin{array}{l}\text { B } \\
(\mathrm{cm})\end{array}$ & $\begin{array}{l}\mathbf{W}_{1} \\
- \\
\mathbf{W}_{2} \\
(\mathrm{~g})\end{array}$ & $\begin{array}{l}\text { L X B B } \\
\left(\mathbf{c m}^{2}\right)\end{array}$ & $\begin{array}{l}\mathrm{DC} \\
\left(\mathrm{g} / \mathrm{cm}^{2}\right)\end{array}$ & $\begin{array}{l}\mathrm{DC}_{\mathrm{A}} \\
\left(\mathrm{g} / \mathrm{cm}^{2}\right)\end{array}$ \\
\hline \multirow[t]{5}{*}{ Albizia saman (Jacq.) Merr. } & 1 & 0.06 & 0.04 & 3.2 & 1.6 & 0.02 & 5.12 & 0.0039 & \multirow{5}{*}{0.00296} \\
\hline & 2 & 0.08 & 0.05 & 4.1 & 1.7 & 0.03 & 6.97 & 0.0043 & \\
\hline & 3 & 0.1 & 0.08 & 6 & 2.2 & 0.02 & 13.2 & 0.0015 & \\
\hline & 4 & 0.09 & 0.07 & 3.3 & 1.6 & 0.02 & 5.28 & 0.0038 & \\
\hline & 5 & 0.14 & 0.12 & 6.7 & 2.3 & 0.02 & 15.41 & 0.0013 & \\
\hline \multirow{5}{*}{ Citrus maxima (Burm.) Merr. } & 1 & 2.14 & 1.96 & 17.9 & 6.2 & 0.18 & 110.98 & 0.0016 & \multirow{5}{*}{0.00194} \\
\hline & 2 & 1.54 & 1.41 & 14.7 & 5.6 & 0.13 & 82.32 & 0.0016 & \\
\hline & 3 & 0.95 & 0.89 & 11.0 & 4 & 0.06 & 44 & 0.0014 & \\
\hline & 4 & 0.96 & 0.86 & 9.6 & 3.9 & 0.1 & 37.44 & 0.0027 & \\
\hline & 5 & 1.02 & 0.93 & 10 & 3.7 & 0.09 & 37 & 0.0024 & \\
\hline \multirow[t]{5}{*}{ Ficus racemosa $\mathrm{L}$. } & 1 & 3.10 & 2.56 & 18.5 & 8.2 & 0.54 & 151.7 & 0.0035 & \multirow{5}{*}{0.00292} \\
\hline & 2 & 0.77 & 0.71 & 10 & 5.5 & 0.06 & 55 & 0.0011 & \\
\hline & 3 & 2.32 & 2.14 & 16.8 & 7.1 & 0.18 & 119.28 & 0.0015 & \\
\hline & 4 & 2.76 & 1.96 & 14.6 & 7.4 & 0.8 & 108.04 & 0.0074 & \\
\hline & 5 & 2.45 & 2.34 & 13.9 & 7 & 0.11 & 97.3 & 0.0011 & \\
\hline \multirow[t]{5}{*}{ Saraca asoca (Roxb.) Willd. } & 1 & 0.86 & 0.72 & 16.1 & 4.2 & 0.14 & 67.62 & 0.0021 & \multirow{5}{*}{0.00128} \\
\hline & 2 & 0.88 & 0.8 & 16.2 & 4.8 & 0.08 & 77.76 & 0.0010 & \\
\hline & 3 & 0.67 & 0.62 & 13.3 & 4.6 & 0.05 & 61.18 & 0.0008 & \\
\hline & 4 & 1.08 & .98 & 18.2 & 5.1 & 0.1 & 92.82 & 0.0011 & \\
\hline & 5 & 0.62 & 0.54 & 13.6 & 4.1 & 0.08 & 55.76 & 0.0014 & \\
\hline \multirow{5}{*}{$\begin{array}{l}\text { Tabernaemontana divaricata (L.) } \\
\text { R.Br. ex Roem. \& Schult. }\end{array}$} & 1 & 0.09 & 0.06 & 9.1 & 2.7 & 0.03 & 24.57 & 0.0012 & \multirow{5}{*}{0.00102} \\
\hline & 2 & 0.04 & 0.02 & 8.3 & 2.4 & 0.02 & 19.92 & 0.0010 & \\
\hline & 3 & 0.11 & 0.09 & 9.6 & 3.1 & 0.02 & 29.76 & 0.0007 & \\
\hline & 4 & 0.10 & 0.07 & 10 & 2.9 & 0.03 & 29 & 0.0010 & \\
\hline & 5 & 0.11 & 0.08 & 10.2 & 2.5 & 0.03 & 25.5 & 0.0012 & \\
\hline \multirow[t]{5}{*}{ Artocarpus heterophyllus Lam. } & 1 & 2.67 & 2.57 & 12.5 & 8 & 0.1 & 100 & 0.001 & \multirow{5}{*}{0.00104} \\
\hline & 2 & 3.25 & 3.08 & 14.5 & 8.5 & 0.17 & 123.25 & 0.0014 & \\
\hline & 3 & 2.97 & 2.79 & 14.7 & 8.6 & 0.18 & 126.42 & 0.0014 & \\
\hline & 4 & 2.24 & 2.18 & 11.9 & 8.2 & 0.06 & 97.58 & 0.0006 & \\
\hline & 5 & 1.94 & 1.86 & 14.7 & 7.1 & 0.08 & 104.37 & 0.0008 & \\
\hline \multirow[t]{5}{*}{ Hibiscus rosa-sinensis $\mathrm{L}$. } & 1 & 0.70 & 0.63 & 8 & 6.3 & 0.07 & 50.4 & 0.0014 & \multirow{5}{*}{0.00166} \\
\hline & 2 & 1.39 & 1.27 & 9.4 & 8.5 & 0.12 & 79.9 & 0.0015 & \\
\hline & 3 & 0.92 & 0.84 & 8.2 & 7 & 0.08 & 57.4 & 0.0014 & \\
\hline & 4 & 1.16 & 1.04 & 9.4 & 8.3 & 0.12 & 78.02 & 0.0015 & \\
\hline & 5 & 0.46 & 0.37 & 6.7 & 5.4 & 0.09 & 36.18 & 0.0025 & \\
\hline \multirow[t]{5}{*}{ Nerium oleander $\mathbf{L}}$. & 1 & 1.14 & 1.09 & 18.5 & 2.3 & 0.05 & 42.55 & 0.0012 & \multirow{5}{*}{0.00136} \\
\hline & 2 & 1.24 & 1.20 & 18.2 & 2.2 & 0.04 & 40.04 & 0.0010 & \\
\hline & 3 & 0.44 & 0.41 & 12.3 & 1.6 & 0.03 & 19.68 & 0.0015 & \\
\hline & 4 & 0.56 & 0.51 & 14.5 & 1.6 & 0.05 & 23.2 & 0.0022 & \\
\hline & 5 & 0.45 & 0.43 & 12.8 & 1.7 & 0.02 & 21.76 & 0.0009 & \\
\hline \multirow[t]{5}{*}{ Mangifera indica $\mathrm{L}$. } & 1 & 1.93 & 1.76 & 9.7 & 5.7 & 0.17 & 55.29 & 0.0031 & \multirow{5}{*}{0.003225} \\
\hline & 2 & 3.13 & 2.66 & 24.5 & 6.8 & 0.47 & 166.6 & 0.0028 & \\
\hline & 3 & 4.65 & 4.1 & 26.1 & 5.9 & 0.55 & 153.99 & 0.0036 & \\
\hline & 4 & 3.65 & 2.87 & 25.2 & 6.8 & 0.78 & 171.36 & 0.0046 & \\
\hline & 5 & 5.14 & 4.41 & 27.5 & 7.8 & 0.73 & 214.5 & 0.0034 & \\
\hline \multirow[t]{4}{*}{ Ixora coccinea $\mathrm{L}}$. & 1 & 1.03 & .94 & 15.2 & 4.3 & 0.09 & 65.36 & 0.0014 & \\
\hline & 2 & 2.27 & 2.13 & 16.8 & 6.1 & 0.14 & 102.48 & 0.0014 & \\
\hline & 3 & 1.35 & 1.27 & 12.5 & 4.9 & 0.08 & 61.25 & 0.0013 & 0.00154 \\
\hline & 4 & 1.27 & 1.2 & 11.6 & 4.5 & 0.07 & 52.2 & 0.0013 & \\
\hline
\end{tabular}




\begin{tabular}{|c|c|c|c|c|c|c|c|c|c|}
\hline & 5 & 1.33 & 1.19 & 12.5 & 4.7 & 0.14 & 58.75 & 0.0023 & \\
\hline \multirow[t]{5}{*}{ Nyctanthes arbor-tristis L. } & 1 & 0.85 & 0.67 & 10.8 & 5.6 & 0.18 & 60.48 & 0.003 & \multirow{5}{*}{0.00262} \\
\hline & 2 & 0.54 & 0.41 & 8.4 & 4.3 & 0.13 & 36.12 & 0.0036 & \\
\hline & 3 & 0.94 & 0.8 & 11.1 & 6 & 0.14 & 66.6 & 0.0021 & \\
\hline & 4 & 1.80 & 1.68 & 9.5 & 9 & 0.12 & 85.5 & 0.0014 & \\
\hline & 5 & 0.25 & 0.16 & 7.4 & 4.1 & 0.09 & 30.34 & 0.003 & \\
\hline \multirow[t]{5}{*}{ Cajanus cajan (L.) Millsp. } & 1 & 0.11 & 0.09 & 5.7 & 2.1 & 0.02 & 11.97 & 0.0017 & \multirow{5}{*}{0.00266} \\
\hline & 2 & 0.1 & 0.08 & 4.5 & 1.7 & 0.03 & 7.65 & 0.0039 & \\
\hline & 3 & 0.07 & 0.05 & 4.9 & 1.8 & 0.02 & 8.82 & 0.0023 & \\
\hline & 4 & 0.13 & 0.10 & 5.5 & 2.2 & 0.03 & 12.1 & 0.0025 & \\
\hline & 5 & 0.09 & 0.07 & 4.6 & 1.9 & 0.02 & 8.74 & 0.0029 & \\
\hline
\end{tabular}

Where, $\mathrm{W}$ is dust content $(\mathrm{g}), \mathrm{W}_{1}$ is initial weight of filter paper, $\mathrm{W}_{2}$ is final weight of filter paper with dust, and "a" is total area of the leaf $\left(\mathrm{cm}^{2}\right)$.

Leaf Area:-

Leaves were blotted dry and then the individual leaf area $(\mathrm{cm} 2)$ was calculated by traceing on graph paper and dust retention was calculated in $\mathrm{g} / \mathrm{cm}^{2}$ (Chaphekar et al. 1980).

\section{Results and Discussion:-}

The amounts of dustfall recorded on the foliar surfaces of different selected plant species are given in the table 2 . $\mathrm{L} \mathrm{X} \mathrm{B}=$ Total leaf area (a), $\mathrm{W}_{1}-\mathrm{W}_{2}=$ Weight of the dust, $\mathrm{DC}=$ Dust Capturing Potential (W), $\mathrm{DC}_{\mathrm{A}}=$ Average of DC

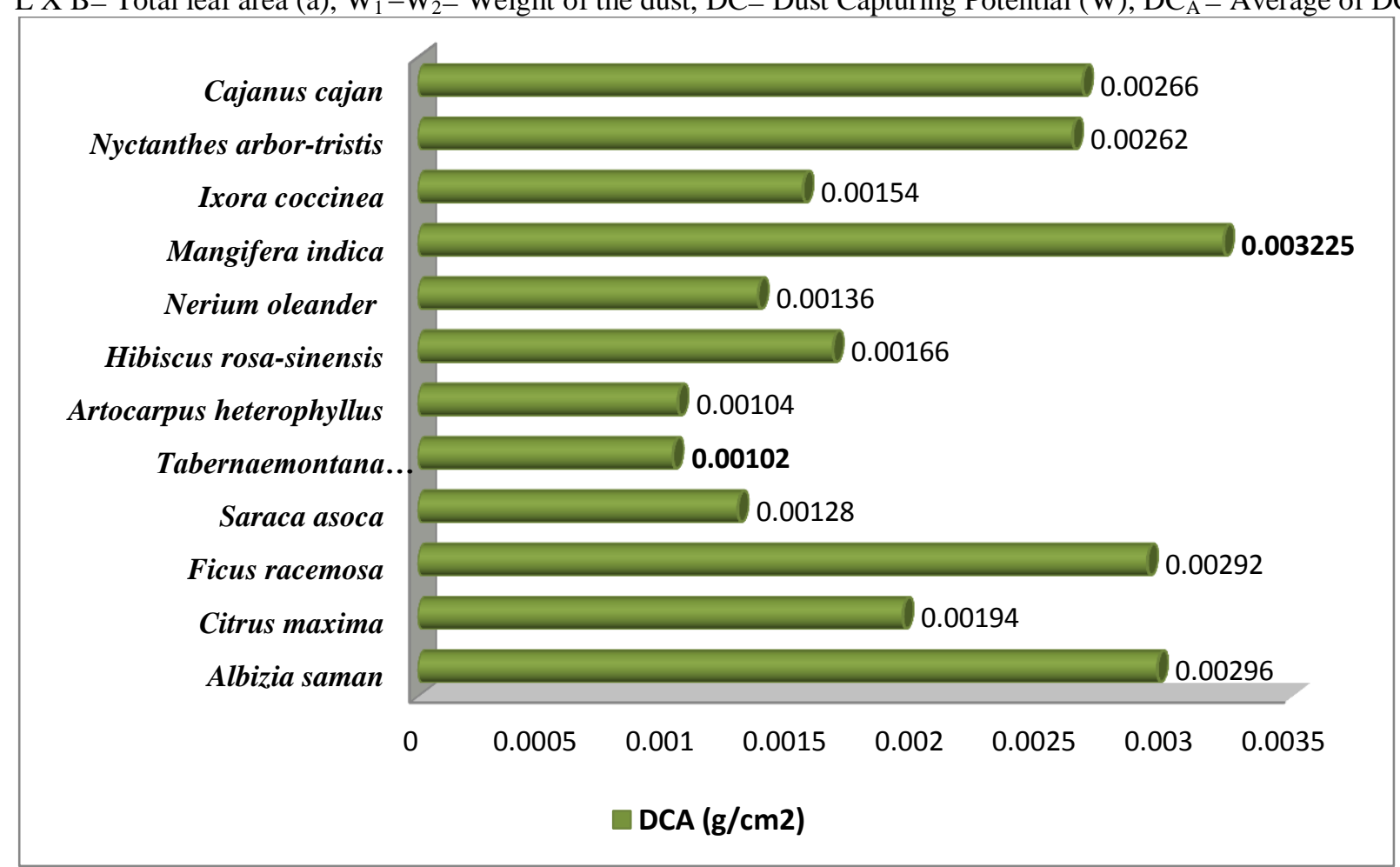

Figure 2:- Graphical representing of Dust Capturing Potential of different Plant species.

The perusal of data revealed that accumulation of dust on leaves varied in different species, (Table 2). It is evident that range of dust deposition varies from $0.003225 \mathrm{~g} / \mathrm{cm}^{2}$ to $0.00102 \mathrm{~g} / \mathrm{cm}^{2}$ of selected plant species.Among plant species, highest dust accumulation was recorded in Mangifera indica $\left(0.003225 \mathrm{~g} / \mathrm{cm}^{2}\right)$ and followed the descending order by Albizia saman $\left(0.00296 \mathrm{~g} / \mathrm{cm}^{2}\right)$, Ficus racemosa $\left(0.00292 \mathrm{~g} / \mathrm{cm}^{2}\right)$ whereas, lowest was noticed in Tabernaemontana divaricata $\left(0.00102 \mathrm{~g} / \mathrm{cm}^{2}\right)$ followed by Artocarpus heterophyllus $\left(0.00104 \mathrm{~g} / \mathrm{cm}^{2}\right)$. The trend of dust trapping capacity among the differentplant species was:Mangifera indica>Albizia saman $>$ Ficus racemosa $>$ Cajanus cajan $>$ Nyctanthes arbor-tristis $>$ Citrus maxima $>$ Hibiscus rosa-sinensis $>$ Ixora coccinea $>$ Nerium oleander $>$ Saraca asoca $>$ Artocarpus heterophyllus $>$ Tabernaemontana divaricata . 


\section{Conclusion:-}

The present work illustrates the significant variation in pattern of dust accumulation on leaves of different plants. Many workers have reported dust accumulation influenced by leaf characteristic of plants( leaf structure, phyllotaxy, presence/absence of hairs, presence of wax on leaf surface, size of petioles, and canopy structure) (Younis et al., 2013). Among plant species, highest dust accumulation, was noticed in Mangifera indica, compared to other species and this may be ascribed to lanceolate, acuminate, coriaceous, long petiole. Whereas, lowest dust load on Tabernaemontana divaricata, may be due to surface smoothness and small leaf surface area. Those plants growing at a less distance from road have more chances of dust accumulation on their leaves which may be due to high dust concentration by vehicles. The present study reveals that evaluation of leaf dust accumulation on plants might be very useful in the selection of appropriate roadside plant species as biomarkers is an inexpensive technique. The result clearly indicate Mangifera indica, Albizia saman, Ficus racemosa showsgood potential of accumulating dust pollution and thus offers an bio filter for urban ecosystem restoration and their cultivation along the road side, industrial areas to abate the dust pollution.

\section{Acknowledgement:-}

All authors wishes to acknowledge the Department of Botany, University of Burdwan for providing the laboratory and other facilities. They are grateful to The Head of the Botany Department.

\section{References:-}

1. Beckett, K. P., Freer-Smith, P.H. and Taylor, G. (1998): Urban woodlands: their role in reducing the effects of particulate pollution. Environmental Pollution, 99: 347-360.

2. Bhattacharya, T., Chakraborty, S., Fadadu, B. and Bhattacharya, P. (2011): Heavy metal concentration in street and leaf deposited dust in Anand city, India. R. J. Chem. Sci., 1(5): 61-66.

3. Borja-Aburto, V.H., Castillejos, M., Gold, D.R., Bierzwinski, S. and Loomis, D. (1998): Mortality and ambient fine particles in southwest Mexico city, 1993-1995. Environ. Health Perspect, 106:849-855.

4. Chaphekar, S.B., Boralkar, D.B. and Shetye, R.P., (1980): Plants for air monitoring in industrial area. Furtado. J.I. (Ed.) Tropical Ecology and development, I.S.T.E. Kuala Lampur, 669-675.

5. Fowler, D., Cape, J.N. and Unsworth, M.H.(1989): Deposition of atmospheric pollutants on forests. Philosophical Transactions of the Royal Society B 324 (1223):247-265.

6. Kaler, N. S, Bhardwaj, S.K., Pant, K.S. and Rai,T.S. (2016): Determination of Leaf Dust Accumulation on Certain Plant Species Grown Alongside National Highway- 22, India. Current World Environment, 11(1): 7782.

7. Leys, J.F., Larney, F.J., Muller, J.F., (1998): Anthropogenic dust and endosulfan emissions on a cotton farm in northern New South Wales, Australia.The Science of the Total Environment 220: 55-70.

8. Manins, P., Allan, R., Beer T., (2001): Atmosphere. Australia State of the Environment Report (Theme Report), CSIRO Publishing, Melbourne, Australia.

9. Nitesh, C.J., Ambika, N.J. and Alkama, G. F., (2017): Efficiency of Bougainvillea spectabilis Willd in Monitoring Dust. International Journal of Applied Environmental Sciences 12(5): 773-785.

10. Prajapati, S. K. and Tripathi, B. D.(2008): Seasonal Variation of Leaf Dust Accumulation and Pigment Content in Plant Species Exposed to Urban Particulates Pollution. J. Environ. Qual. 37:865-870.

11. Rai, P.K. (2016): Biodiversity of roadside plants and their response to air pollution in an Indo-Burma hotspot region: implications for urban ecosystem Restoration. Journal of Asia-Pacific Biodiversity 9:47-55.

12. Samal, A.K. and Santra, S.C. (2002): Air quality of Kalyani Township (Nadia, West Bengal) and its impact on surrounding vegetation. Ind. J. Environ. Health (44): 71-76.

13. Swain, S., Mallick, S.N., Prasad, P. (2016): Effect of industrial dust deposition on photosynthetic pigment chlorophyll and growth of selected plant species in Kalunga Industrial areas, Sundargarh, Odisha. International Journal of Botany Studies. 1(5):01-05.

14. Younis, U., Bokhari, T.Z., Malik, S.A., Ahmad, S. \& Raja, R., (2013): Variations in Leaf Dust Accumulation, Foliage and Pigmentattributes in Fruiting Plant Species Exposed To Particulatepollution From Multan. International Journal of Agricultural Science and Research (IJASR) 3(3):1-12. 